\title{
Experience in totally implantable venous port catheter: Analysis of 3,000 patients in 12 years
}

\author{
Tamamen implante edilebilir venöz port kateter deneyimi: 12 yılda 3000 hastanın analizi
}

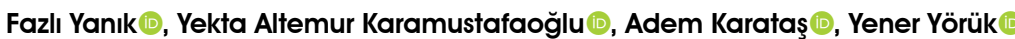 \\ Department of Thoracic Surgery, Medicine Faculty of Trakya University, Edirne, Turkey
}

\begin{abstract}
Background: This study aims to present our experience with patients who were performed totally implantable venous port catheter.

Methods: Demographics-clinical features, surgical results and complications of 3,000 patients (1,824 males, 1,176 females; mean age $61.04 \pm 11.5$ years; range, 18 to 88 years) who were performed totally implantable venous port catheter between March 2005 and March 2017 were evaluated retrospectively. Totally implantable venous port catheter indications, complications, catheter duration of stay, reasons for catheter removal and statistical analysis information were reported in detail by reviewing patient records.
\end{abstract}

Results: Of the cases, the Seldinger method was used in 98\%, $1 \%(\mathrm{n}=36)$ had the catheter inserted with superficial Doppler ultrasonography, while the veins were not found in $1 \%(\mathrm{n}=29)$ and these patients were excluded from the study. Totally implantable venous port catheter was inserted via right internal jugular vein in 2,095 patients (70\%), via right subclavian vein in 470 patients $(16 \%)$, via left internal jugular vein in 290 patients $(10 \%)$, and via left subclavian vein in 106 patients $(3 \%)$. Mean duration of stay for totally implantable venous port catheter was 46.7 months (range, 1 to 78 months). Complications were detected in a total of 288 patients $(9.6 \%), 153(5.1 \%)$ being early and $135(4.5 \%)$ being late. The most common oncologic indication was colorectal cancer. The rate of port removal was 298/3,000 (9.9\%) and the main reasons were infection, thrombosis, pain, and end of treatment. Totally implantable venous port catheter was required to be inserted twice in 33 patients $(1 \%)$ and thrice in 14 patients $(0.5 \%)$. Totally implantable venous port catheter had malposition in eight patients and all were revised successfully with over the guide method.

Conclusion: Totally implantable venous port catheter may increase the quality of life in cancer patients. Despite possible complications, totally implantable venous port catheter is safe and comfortable for long-term intravenous treatment. Possible complications may be prevented or managed when totally implantable venous port catheter is performed by surgeons with adequate experience.

Keywords: Catheter; central vein; implantable; port. $\ddot{o z}$

Amaç: Bu çalışmada tamamen implante edilebilir venöz port kateter uygulanan hastalar ile deneyimimiz sunuldu.

Çalışma planı: Mart 2005 - Mart 2017 tarihleri arasında tamamen implante edilebilir venöz port kateter uygulanan 3000 hastanın (1824 erkek, 1176 kadın; ort. yaş $61.04 \pm 11.5$ yıl; dağ $11 ı$, $18-88$ yıl) demografik-klinik özellikleri, cerrahi sonuçları ve komplikasyonları retrospektif olarak değerlendirildi. Tamamen implante edilebilir venöz port kateter endikasyonları, komplikasyonları, kateter kalış süresi, kateter çıkarma nedenleri ve istatistiksel analiz bilgileri hasta kayıtları incelenerek detaylı bir şekilde sunuldu.

Bulgular: Olguların \%98'inde Seldinger yöntemi kullanıldı, \%1'inde $(n=36)$ kateter yüzeyel Doppler ultrasonografi ile takıldı, \%1'inde $(n=29)$ ise damar bulunamadı ve bu hastalar çalışmadan çıkarıldı. Tamamen implante edilebilir venöz port kateter 2095 hastada (\%70) sağ internal jugüler ven yoluyla, 470 hastada (\%16) sağ subklavvan ven yoluyla, 290 hastada (\%10) sol internal jugüler ven yoluyla ve 106 hastada (\%3) sol subklavyan ven yoluyla takıldı. Tamamen implante edilebilir venöz port kateter ortalama kalış süresi 46.7 ay (dağılım, 1-78 ay) idi. Toplam 288 hastada (\%9.6), 153'ü (\%5.1) erken ve 135 'i (\%4.5) geç olmak üzere komplikasyonlar tespit edildi. En sık görülen onkolojik endikasyon kolorektal kanser idi. Port çıkarma oranı 298/3000 (\%9.9) idi ve başlıca nedenler enfeksiyon, tromboz, ağrı ve tedavinin sona ermesi idi. Tamamen implante edilebilir venöz port kateter 33 hastaya (\%1) iki kez, 14 hastaya (\%0.5) üç kez takılmak zorunda kalındı. Tamamen implante edilebilir venöz port kateter sekiz hastada malpozisyonlu idi ve bunların tamamı kılavuz tel yöntemiyle başarıyla revize edildi.

Sonuç: Tamamen implante edilebilir venöz port kateter kanser hastalarında yaşam kalitesini artırabilir. Olası komplikasyonlara rağmen, tamamen implante edilebilir venöz port kateter uzun süreli intravenöz tedavi için güvenli ve konforludur. Tamamen implante edilebilir venöz port kateter yeterli deneyime sahip cerrahlarca uygulandığında olası komplikasyonlar önlenebilir veya yönetilebilir.

Anahtar sözcïkler: Kateter; santral ven; implante edilebilir; port.

Received: September 28, 2017 Accepted: December 05, 2017

Correspondence: Fazlı Yanık, MD. Trakya Üniversitesi Tıp Fakültesi Göğüs Cerrahisi Anabilim Dalı, 22030 Edirne, Turkey. Tel: +90 284 - 2357641 e-mail: fazliyanik@hotmail.com 
Totally implantable venous port catheter (TIVPC) is a method that facilitates quality of life for cancer patients, particularly for those who require chemotherapy, parenteral treatment or repeated blood tests. In the treatment of cancer patients, use of TIVPC has increased in recent years because of frequent venous access, long therapy time, use of sclerosing agents and excessive amount of fluid. In this way, the applications become more hygienic and the catheter can be easily accepted by the patients as cosmetics. ${ }^{[1,2]}$ Totally implantable venous port catheter can be easily placed with daily hospitalization under local anesthesia in the vast majority of cases. Low infection rate and normal physical activity are advantages. However, this method is not entirely innocent due to side effects such as infection, thrombosis, pneumothorax, catheter fracture and migration. ${ }^{[3]}$ Therefore, in this study, we aimed to present our experience with patients who were performed TIVPC.

\section{PATIENTS AND METHODS}

Demographics-clinical features, surgical results and complications of 3,000 patients $(1,824$ males, 1,176 females; mean age $61.0 \pm 11.5$ years; range, 18 to 88 years) who were performed TIVPC at Medicine Faculty of Trakya University between March 2005 and March 2017 were evaluated retrospectively. Information about the the details of port indications, complications, duration of stay for catheter, reasons for catheter removal and statistical analysis of data were reported from patient records. Cases with insufficient file information, patients under 18 years of age and those with sedative or local anesthetic allergy, and those in whom TIVPC could not be inserted despite all punctures were excluded. The study protocol was approved by the Medicine Faculty of Trakya University Ethics Committee. The study was conducted in accordance with the principles of the Declaration of Helsinki.

\section{Patients and operational technique}

The catheter was inserted in the presence of local anesthesia and/or sedo-analgesia. Subclavian or internal jugular veins (IJVs) were used. All catheters were inserted by the same surgical team in an operating theater. All patients were provided with continuous monitoring using pulse oximetry, electrocardiography, and a noninvasive blood pressure.

As a first choice, IJV was preferred. Of the cases, the Seldinger method was used in 98\%, $1 \%$ had the catheter inserted with superficial Doppler ultrasonography (USG), while the veins were not found in $1 \%$. Right side was used initially in all patients, but the contralateral side was preferred in patients who had undergone mastectomy, previous radiotherapy or surgery of the head and neck, or those with structural anomalies etc. The insertion port for subclavian vein (SCV) is the right middle infra subclavian area from the junction of the outer clavicle to the lowest landmark of the suprasternal notch and for IJV the patient is placed in Trendelenburg position with face turned to left side to well exposed right IJV.

The needle was advanced with negative aspiration through the sternocleidomastoid muscle's intersection of the two legs with an angle of 45 degrees towards the nipple. After the venous blood was aspirated, the wire was advanced until arrhythmia was inspected. If arrhythmia was not inspected or there was doubt, the location of the wire was checked by fluorescent scopy. A pocket was created just below the distal portion of the clavicle (conoid tubercle) for the port insertion with a $3 \mathrm{~cm}$ incision.

A tunnel was formed in this region from the cervical region for internal jugular vein access. For the SCV access, there is no need to create this tunnel and the catheter was directly inserted to the SCV. A radiopaque titanium body and a silicone catheter with a diameter of $8 \mathrm{~F}$ were used (Figure 1). Following the delivery of the guide wire, a vascular dilator was inserted by using a $0.5 \mathrm{~cm}$ incision into the access site of the guide wire. The catheter was inserted over the guide wire according to the calculated length on the patient before the procedure. The length of the catheter was calculated from the port to the angulus sternum. All TIVPCs had single lumen catheter and were controlled with easily flushed blood withdrawn from line before and after use. After the procedure, the port was filled with a solution containing $0.2 \mathrm{~mL}$ heparin $(100 \mathrm{U} / \mathrm{mL})$ and $5 \mathrm{~mL} 0.009$ sodium chloride via a small non-coring (Huber) needle and thus was

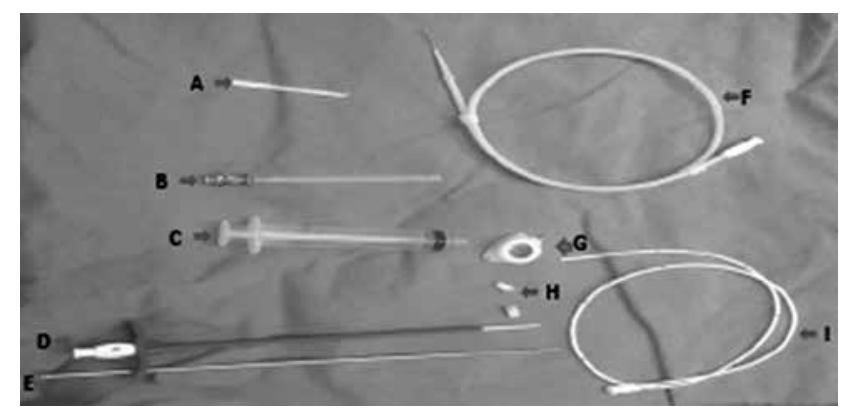

Figure 1. Materials used during totally implantable venous port catheter insertion.

A: Vein extractor; B: Puncture needle; C: Puncture syringe; D: Breakable dilator; E: Tunneler; F: Wire guide; G: Radio opaque port reservoir; H: Catheter lock; I: Radio opaque silicone catheter. 
Table 1. Indications for totally implantable venous port catheter $(n=3,000)$

\begin{tabular}{lcc}
\hline Malignancy type & $\mathrm{n}$ & $\%$ \\
\hline Colorectal cancer & 695 & 25 \\
Breast cancer & 598 & 20 \\
Gastric cancer & 424 & 14 \\
Hematologically-derived cancers & 305 & 10 \\
Ovarian cancer & 244 & 8 \\
Pancreatic cancer & 209 & 7 \\
Sarcomas & 159 & 5 \\
Hepatocellular carcinoma & 121 & 4 \\
Renal cell carcinoma & 117 & 4 \\
Esophageal cancer & 62 & 2 \\
Lung cancer & 35 & 1 \\
For non-oncological reasons & 31 & 1 \\
\hline
\end{tabular}

protected from obstruction. Catheters were flushed monthly if patients were given monthly chemotherapy or had catheter in situ. All patients were checked after insertion of the catheter with chest X-ray to see the localization of the catheter or to detect any complication. Patients were sent home after four to six hours of follow-up. The complications related to port implantation were recorded as early and late: early is before the first chemotherapy application and late is after. The numbers and reasons of catheter removal were also recorded. All patients were treated orally with simple first step antibiotics (first-generation cephalosporin) for five days. In patients with very thin subcutaneous tissue or in reoperated patients due to skin decubitus, the port was buried under the pectoral muscle. Totally, 144 patients (5\%) had a skin decubitus on the port. Although the port was shifted and buried under the pectoral muscle, we had to remove the catheter in $121(3 \%)$ of these cases.

\section{Statistical analysis}

Statistical analysis was performed using IBM SPSS version 20.0 software (IBM Corp., Armonk, NY, USA). Descriptive statistics were used in number and percentage, including mean \pm standard deviation, median and range, frequencies and proportions.

\section{RESULTS}

Indications for TIVPC were summarized in Table 1. The TIVPC was inserted via right IJV in 2,095 patients $(70 \%)$, via right SCV in 470 patients $(16 \%)$, via left IJV in 290 patients (10\%), and via left SCV in 106 patients (3\%) (Table 2). In 36 patients (1\%), the vein was found via Doppler USG. In 29 patients (1\%), the TIVPC could not be inserted despite all punctures although Doppler USG was also used. These cases were excluded from the study.

Average duration of stay for TIVPC was 46.7 months (range, 1-78 months). Complications were detected in 288 patients $(9.6 \%)$. As early complications (before the first chemotherapy), arterial puncture developed immediately after the procedure in $4 \%$ of patients and pneumothorax in $1 \%$ of patients. Tube thoracostomy was needed for 20 patients with massive pneumothorax and arterial hemorrhage was managed by compression after arterial puncture. In a few days, the hematoma due to artery puncture was regressed. Right pneumothorax developed in a patient with left pneumonectomy while placing TIVPC. When noticed on chest X-ray, emergency tube thoracostomy and intubation were applied. He was discharged after two days of intensive care hospitalization.

Table 2. Surgical outcomes for totally implantable venous port catheter $(n=3,000)$

\begin{tabular}{lcccc}
\hline & $\mathrm{n}$ & $\%$ & Mean \pm SD & Range \\
\hline Age (year) & & & $61.0 \pm 11.5$ & $18-88$ \\
Gender & 1,824 & 61 & & \\
$\quad$ Male & 1,176 & 39 & & $10-55$ \\
$\quad$ Female & & & $16.1 \pm 5.7$ & $1-118$ \\
Mean operation time & & & $42.3 \pm 11.8$ & \\
Mean port catheter duration time (month) & 3,000 & 100 & & \\
Access of implementation & 484 & 16 & & \\
Right subclavian vein & 117 & 4 & & \\
Left subclavian vein & 2,111 & 70 & & \\
Right internal jugular vein & 288 & 10 & & \\
Left internal jugular vein & & & \\
\hline
\end{tabular}

SD: Standard deviation. 

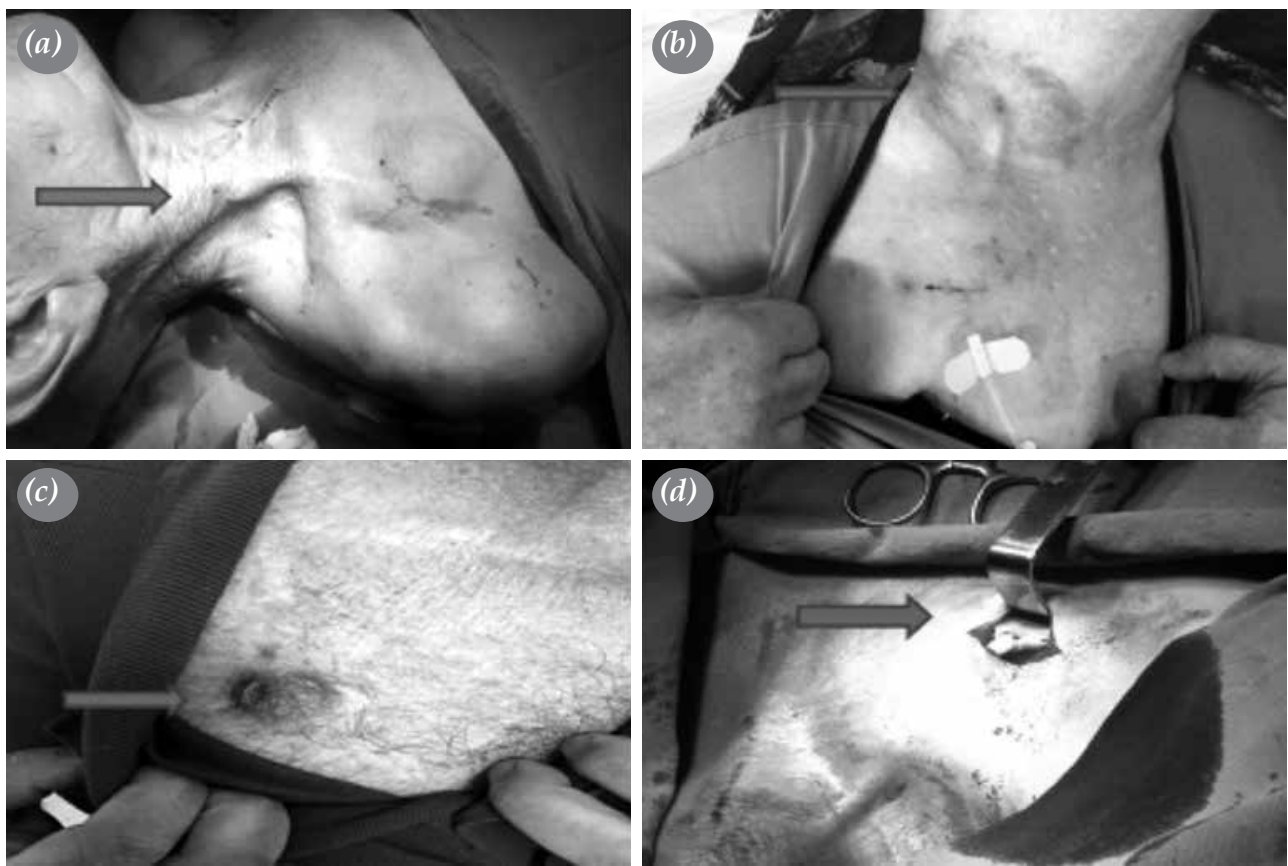

Figure 2. (a) Intraoperative view after totally implantable venous port catheter is attached to internal jugular vein. (b) Ecchymosis in cervical region after arterial puncture from early complications. (c) View of skin decubitus on port. (d) View of reservoir rotation as a rare complication.

As two of the most common late complications (after the first chemotherapy), skin decubitus on the port was detected in 144 patients (5\%), while wound infections developed in 90 patients (3\%) (Figure 2, Table 3). All 144 patients who developed skin decubitus underwent revision, but in only $23(16 \%)$ was the attempt successful. The catheters had to be removed in $121(84 \%)$ of these patients. Cultures were negative in 90 patients. Wound infection was treated with empirical antibotics. Microbiological examination identified methicillinsensitive Staphylococcus aureus in four patients and Candida albicans in three patients. The first catheter was removed in these seven patients and they were successfully treated with sensitive antibiotics. Port catheter was removed in all 24 patients who developed venous thrombosis and appropriate anticoagulant therapy was given. Low molecular weight heparin (Enoxaparin sodium $1 \mathrm{mg} / \mathrm{kg}$ ) was used as the anticoagulant agent. The TIVPC was implanted in the right SCV in three patients but it migrated to the right internal jugular vein during follow-up (Figure 3). Totally implantable venous port catheter was inserted in right internal jugular vein in five patients but it migrated to the right SCV. The catheter was revised successfully with over the guide method in all of them. Patients with reservoir fracture and rotation were successfully revised using the old incision scar. In two patients who developed pinch off syndrome, the subclavian catheter was removed and a jugular catheter was placed. A catheter piece migrated to right ventricle in two patients whose catheter was broken. We did not consider a surgical intervention for the patients whose

Table 3. Early and late period complications of totally implantable venous port catheter

\begin{tabular}{lcc}
\hline & $\mathrm{n}$ & $\%$ \\
\hline Early complications & 153 & 5 \\
Arterial puncture & 127 & 4 \\
Pneumothorax & 26 & 1 \\
Late complications & 279 & 9.5 \\
Skin decubitus & 144 & 5 \\
Wound infection & 90 & 3 \\
Vein thrombosis & 21 & 1 \\
Catheter malposition & 8 & 0.2 \\
Catheter occlusion & 4 & 0.12 \\
Reservoir fracture & 4 & 0.12 \\
Reservoir rotation & 4 & 0.12 \\
Catheter fracture & 2 & 0.06 \\
Pinch-off syndrome & 2 & 0.06 \\
\hline
\end{tabular}



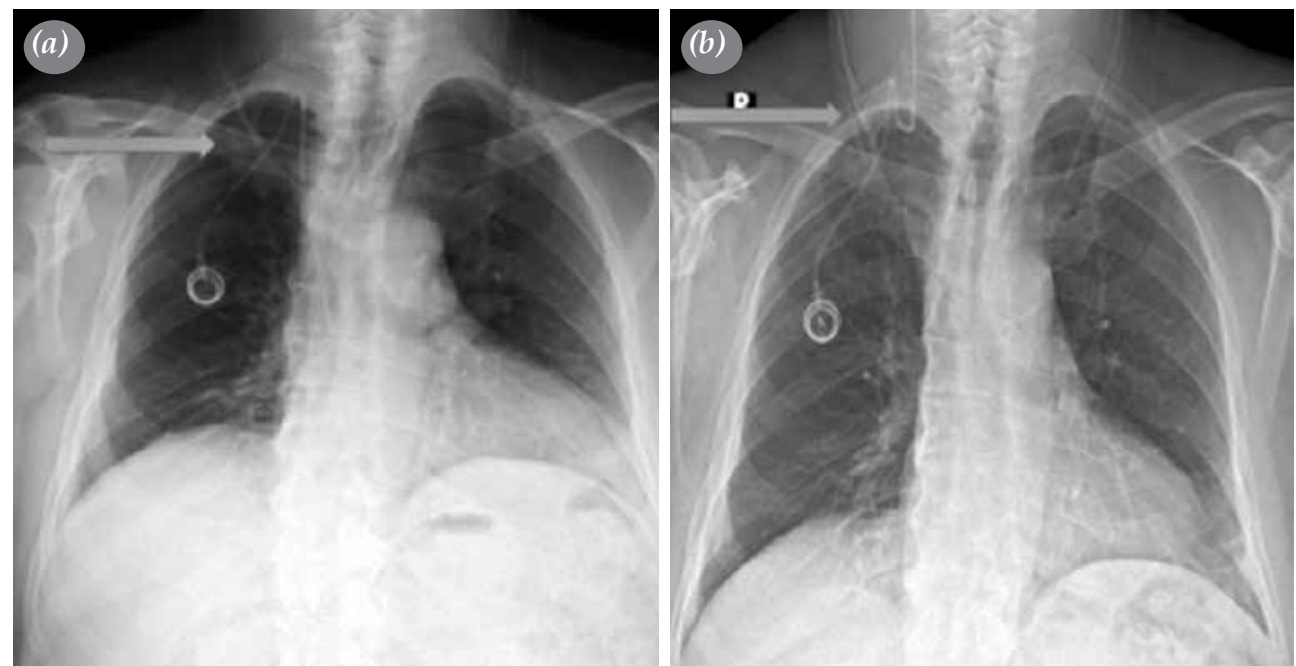

Figure 3. (a) Correct chest X-ray image of totally implantable venous port catheter implanted through right subclavian vein, two months before. (b) Malpositioned chest X-ray image of totally implantable venous port catheter to internal jugular vein.

catheter was broken because of low life-expectancy and poor general status for anesthesia. For these two patients, the broken catheter piece was proposed to be removed with a snare technique by transcatheter, but the procedure was denied by the patients and their relatives due to the poor general condition of the patients. The first patient died after one month and the second patient after three months because of tumor progression. Anticoagulant therapy (low molecular weight heparin, enoxaparin sodium $1 \mathrm{mg} / \mathrm{kg}$ ) was administered during their follow-up period.

In one case, the catheter was accidentally inserted into the internal carotid artery. After arterial blood flushing, the catheter was removed immediately with no neurological symptoms.

The rate of port removal was 298/3,000 (10\%) with reasons such as infection, end of treatment, pain, and

Table 4. Totally implantable venous port catheter removal rates

\begin{tabular}{lcc}
\hline Removal reason & $\mathrm{n}$ & $\%$ \\
\hline Infection & 95 & 32 \\
End of treatment & 80 & 26 \\
Pain & 64 & 22 \\
Thrombosis & 24 & 8 \\
Cosmetic problems & 20 & 7 \\
Other (not to aspirate blood, not & 15 & 5 \\
to give fluid to the catheter etc.) & & \\
\hline
\end{tabular}

thrombosis etc. (Table 4). TIVPC was inserted twice in 33 patients (1\%) and thrice in 14 patients $(0.5 \%)$.

\section{DISCUSSION}

Venous ports placed under the skin that are used increasingly in recent years provide significant opportunities particularly for patients who would receive long-term chemotherapy. Repeated chemotherapy may often cause thrombosis and vessel wall damage to the peripheral veins. The need for a new peripheral vascular access after each chemotherapy cure may lead to pain, infection and vascular access difficulties. TIVPCs have important advantages such as low risk of infection, long-term ease of use, no restriction on daily activities and being able to continue therapy at home. ${ }^{[4,5]}$ In our clinic, TIVPC insertion has been gradually increasing in last 12 years. While the number of procedures was approximately 100 cases/year during the preliminary years, it increased to 300 cases/year in recent years.

Retrospective studies of Wang et al. ${ }^{[5]}$ involving 235 cases reported that the mean age of cases was 58.2 years, $62.5 \%$ being female. Totally implantable venous port catheter was applied most commonly in breast, lung and colorectal cancer cases. Internal jugular vein was used in 159 cases (67.7\%) while right side was used in 140 cases (59.6\%). In our study, mean age of the 3,000 cases was 61.04 years, $61 \%$ being male. Totally implantable venous port catheter was applied most commonly in colorectal, breast and gastric cancer cases. Internal jugular vein was used in 2,399 cases $(80 \%)$ while right side was used in 2,595 cases $(86 \%)$. 
Although TIVPCs are considered as the safest way for long-term intermittent central venous access, some early and late complications might occur. Early complications are related to port insertion (pneumothorax, hemothorax, arterial puncture, hematoma, air embolism) or reservoir implantation and indwelling (wound dehiscence, hematoma, seroma, wound infection). Late complications can be divided into two as catheter-related (catheter occlusion, catheter misplacement, upper extremity deep vein thrombosis, port-related bloodstream infection, venous thromboembolism, pinch-off syndrome, catheter embolization) or reservoir-related (reservoir fracture, reservoir rotation, reservoir membrane disruption). ${ }^{[4]} \mathrm{In}$ our study, complications were detected in 286 patients (9.5\%) among whom 5\% had early while $4 \%$ had late complications. We managed these complications successfully (Table 2). We did not observe any patients with air embolism or hemothorax as early complication or catheter embolization or reservoir membrane disruption as late complication. Bacterial contamination of the reservoir with port catheter needle application is considered to be the most frequent route of infection. ${ }^{[6]}$ Compliance with sterility requirements is imperative not only during port catheter placement, but also during preparation of drug solutions and needle application. Thus, good nursing care is important for the TIVPC to be used safely for longer time. A trained chemotherapy nurse should follow a standardized procedure of puncture under sterile conditions with specific needles, using a heparin lock after each access or every four weeks if the system is not in use. ${ }^{[6,7]}$ In a study conducted on 178 intensive care nurses in Hungary, the nurses' knowledge of catheterrelated infections was inadequate and a high incidence of catheter-related infection was reported..$^{[8]} \mathrm{A}$ good catheter care was provided in coordination with the chemotherapy nurses in our oncological program.

Moreover, in a research of Johnson et al. ${ }^{[9]}$ including 2,154 patients undergoing TIVPC placement, 360 patients $(16.7 \%)$ received antibiotic prophylaxis, while $1,794(83.3 \%)$ received no periprocedural antibiotics. Authors identified 27 infections (1.25\%) in the period after the procedure; five occurring in the antibiotic prophylaxis group (1.39\%) and 22 in the nonprophylaxis group $(1.23 \%)$. They concluded that there was no significant difference in infection rate when antibiotic prophylaxis was used. Similarly, Wang et al. ${ }^{[5]}$ reported that the principal reasons for premature catheter removal were port-associated blood stream infection and a suboptimal tip position. The port-associated blood stream infection was more prevalent in hematologic and upper gastrointestinal cancer patients. In our study, we used routine antibiotic prophylaxis an hour before surgery and during the seven days after the procedure with cefuroxime axetil.

A relatively higher risk of complications may be detected in patients in whom IJV, SCV, or external jugular vein access was preferred. Furthermore; femoral, brachial or trapezius placement of TIVPC may be required in cases with a history of multiple central venous catheterizations, bilateral breast cancer, infected tissue or post-radiogenic dermatitis of cutaneous metastasis. ${ }^{[10-12]}$ In our study, we did not use any other access for TIVPC except for IJV and SCV.

Celik et al. ${ }^{[13]}$ defined the cephalic vein cut-down method in their study on 20 patients with vascular access problem. Their method was easy to apply, reliable and non-disadvantaged. They reported low rates of pneumothorax, hemothorax, and life-threatening injuries such as major vascular injury complications. In our study, the TIVPC could not be inserted in 29 patients (1\%) despite all punctures although Doppler USG was used. Cephalic vein cut-down method could be used for these patients.

With increasing use of chemotherapy, TIVPC applications are increasing. Therefore, TIVPC may be preferred in anesthesia, cardiovascular surgery, thoracic surgery, general surgery, interventional radiology, oncology, gynecological oncology, and internal medicine at increasing frequency. ${ }^{[14,15]}$ We believe that the surgical procedure should be performed by surgeons with adequate experience in order to manage the possible early and late complications.

Besirli et al. ${ }^{[16]}$ presented a patient with pulmonary artery embolism due to pinch-off syndrome. They reported that they decided on conservative monitoring because the patient had metastatic colon cancer with short life expectancy. Also, they were aware of the syndrome one month later. In our study, pinch-off syndrome was seen in two cases and conservative follow-up and embolism prophylaxis were performed due to similar reasons. By way of transcatheter, these broken catheter pieces can be removed by snare technique. Otherwise, they may cause thrombosis. Although we advised the transcatheter technique, it was not accepted by the patients and their relatives since patients were in terminal period.

Furthermore, Feo et al. ${ }^{[17]}$ investigated the costefficiency of chest port placements when performed in the operation room or the outpatient clinic. They reported that the average cost for chest port placement was significantly higher when performed in the operation room compared to the outpatient clinic. 
Authors concluded that chest ports can be safely placed in most patients under local anesthesia in the office setting without fluoroscopy or ultrasound guidance. In our study, the TIVPC was performed in the operation room in all cases and the average process and material cost was calculated as 650 Turkish liras.

In the literature, an interval of six days was reported between the placement and the first use of the TIVPC to reduce the removal rate due to complications. Also, intermediate- and high-risk for neutropenia chemotherapy regimens were related to higher port removal rates due to complications compared to lowrisk regimens. ${ }^{[18]}$ For our population, we suggested to start the treatment after the first 24 hours and to perform weekly care.

The strength of this study was the evaluation of a large population $(n=3,000)$, while the main limitation was the data collection not being dedicated to clinical research, causing limited control of the quality and coherence of data. This study mainly describes our extensive experience in the subject.

In conclusion, totally implantable venous port catheters may increase the quality of life as part of the treatment modalities in cancer patients. Despite possible complications, totally implantable venous port catheter is safe for long-term intravenous access. Care for totally implantable venous port catheter care should be provided elaborately by trained and experienced chemotherapy nurses in coordination with surgeons. Implantation of chemotherapy port catheters should be performed by surgeons with adequate experience in order to avoid complications and manage possible problems.

\section{Declaration of conflicting interests}

The authors declared no conflicts of interest with respect to the authorship and/or publication of this article.

\section{Funding}

The authors received no financial support for the research and/or authorship of this article.

\section{REFERENCES}

1. Lebeaux D, Larroque B, Gellen-Dautremer J, Leflon-Guibout V, Dreyer C, Bialek S, et al. Clinical outcome after a totally implantable venous access port-related infection in cancer patients: a prospective study and review of the literature. Medicine (Baltimore) 2012;91:309-18.

2. Carlo JT, Lamont JP, McCarty TM, Livingston S, Kuhn JA. A prospective randomized trial demonstrating valved implantable ports have fewer complications and lower overall cost than nonvalved implantable ports. Am J Surg 2004;188:722-7.

3. Kim JT, Oh TY, Chang WH, Jeong YK. Clinical review and analysis of complications of totally implantable venous access devices for chemotherapy. Med Oncol 2012;29:1361-4.

4. Tabatabaie O, Kasumova GG, Eskander MF, Critchlow JF, Tawa NE, Tseng JF. Totally Implantable Venous Access Devices: A Review of Complications and Management Strategies. Am J Clin Oncol 2017;40:94-105.

5. Wang YC, Lin PL, Chou WH, Lin CP, Huang CH. Longterm outcomes of totally implantable venous access devices. Support Care Cancer 2017;25:2049-54.

6. Rauthe G, Altmann C. Complications in connection with venous port systems: prevention and therapy. Eur J Surg Oncol 1998;24:192-9.

7. Hengartner H, Berger C, Nadal D, Niggli FK, Grotzer MA. Port-A-Cath infections in children with cancer. Eur J Cancer 2004;40:2452-8.

8. Csomós A, Orbán E, Konczné Réti R, Vass E, Darvas K. Intensive care nurses' knowledge about the evidence-based guidelines of preventing central venous catheter related infection. Orv Hetil 2008;149:929-34. [Abstract]

9. Johnson E, Babb J, Sridhar D. Routine Antibiotic Prophylaxis for Totally Implantable Venous Access Device Placement: Meta-Analysis of 2,154 Patients. J Vasc Interv Radiol 2016;27:339-43.

10. Kato K, Iwasaki Y, Onodera K, Higuchi M, Kato K, Kato Y, et al. Totally implantable venous access port via the femoral vein in a femoral port position with CT-venography. J Surg Oncol 2016;114:1024-8.

11. Marcy PY, Magné N, Bailet C, Gallard JC, Valenza B, Schneider M, et al. Brachial fluoroscopically guided implantation of venous port devices in oncology patients. Bull Cancer 2002;89:707-12. [Abstract]

12. Hill S. Trapezius placement of implanted ports: understanding the procedure. Br J Nurs. 2016;25:9-15.

13. Celik A, Sayan M, Teber I, Tuluce K, Demiroz SM, Kurul IC. Central venous port implantation with cephalic vein cutdown method. Turk Gogus Kalp Dama 2013;21:845-8.

14. Di Carlo I, Pulvirenti E, Mannino M, Toro A. Increased use of percutaneous technique for totally implantable venous access devices. Is it real progress? A 27-year comprehensive review on early complications. Ann Surg Oncol 2010;17:1649-56.

15. Vescia S, Baumgärtner AK, Jacobs VR, Kiechle-Bahat $M$, Rody A, Loibl S, et al. Management of venous port systems in oncology: a review of current evidence. Ann Oncol 2008;19:9-15.

16. Besirli K, Demirkaya A, Demirbas MY, K1lı Z "Pinchoff syndrome": an unusual complication following central venous port implantation. Turkish Journal of Thoracic and Cardiovascular Surgery 2010;18:229-231.

17. Feo CF, Ginesu GC, Bellini A, Cherchi G, Scanu AM, Cossu ML, et al. Cost and morbidity analysis of chest port insertion in adults: Outpatient clinic versus operating room placement. Ann Med Surg (Lond) 2017;21:81-4.

18. Kakkos A, Bresson L, Hudry D, Cousin S, Lervat C, Bogart E, et al. Complication-related removal of totally implantable venous access port systems: Does the interval between placement and first use and the neutropeniainducing potential of chemotherapy regimens influence their incidence? A four-year prospective study of 4045 patients. Eur J Surg Oncol 2017;43:689-95. 